\begin{tabular}{|c|c|c|c|c|c|c|c|c|}
\hline \multicolumn{3}{|c|}{$\begin{array}{l}\text { 2. To: (Receiving Organization) } \\
\text { Distribution }\end{array}$} & \multicolumn{2}{|c|}{$\begin{array}{l}\text { 3. From: (Originating Organization) } \\
\text { Nuclear Safety }\end{array}$} & \multicolumn{4}{|c|}{$\begin{array}{l}\text { 4. Related EDT No:: } \\
\qquad \text { N/A }\end{array}$} \\
\hline \multicolumn{3}{|c|}{$\begin{array}{l}\text { 5. Proj./Prog./Dept./Div.: } \\
200 \text { Area ISA FSAR/Spent Nuclear Fuel }\end{array}$} & \multicolumn{2}{|c|}{$\begin{array}{l}\text { 6. Design Authority/ Design Agent/Cog. Engr.: } \\
\text { R. D. Carrell }\end{array}$} & \multicolumn{4}{|c|}{$\begin{array}{l}\text { 7. Purchase Order No.: } \\
\qquad \text { N/A }\end{array}$} \\
\hline \multicolumn{5}{|c|}{ 8. Originator Remarks: } & \multicolumn{4}{|c|}{$\begin{array}{r}\text { 9. Equip./Component No.: } \\
\text { N/A }\end{array}$} \\
\hline \multicolumn{5}{|c|}{ Transmittal for approval and release. } & \multicolumn{4}{|c|}{$\begin{array}{l}\text { 10. System/Bidg. Facility: } \\
\qquad \text { W-518 }\end{array}$} \\
\hline \multirow{3}{*}{\multicolumn{3}{|c|}{ 11. Receiver Remarks: }} & \multirow{3}{*}{\multicolumn{2}{|c|}{ Document? [] Yes [x] No }} & \multicolumn{4}{|c|}{$\begin{array}{l}\text { 12. Major Assm. Dwg. No: } \\
\text { N/A }\end{array}$} \\
\hline & & & & & \multicolumn{4}{|c|}{$\begin{array}{l}\text { 13. Permit/Permit Application No.: } \\
\text { N/A }\end{array}$} \\
\hline & & & & & \multicolumn{4}{|c|}{$\begin{array}{l}\text { 14. Required Response Date: } \\
\text { N/A }\end{array}$} \\
\hline \multicolumn{2}{|l|}{15.} & \multicolumn{3}{|c|}{ DATA TRANSMITTED } & (F) & (G) & $(\mathrm{H})$ & (I) \\
\hline $\begin{array}{l}(A) \\
\text { lem } \\
\text { No. }\end{array}$ & (B) Documentudrawing No. & $\begin{array}{l}\text { (C) } \\
\text { Sheet } \\
\text { No. }\end{array}$ & $\begin{array}{l}\text { (D) } \\
\text { Rev. } \\
\text { No. }\end{array}$ & (E) Titte or Description of Data Transmitted & $\begin{array}{l}\text { Approval } \\
\text { Designator }\end{array}$ & $\begin{array}{l}\text { Reason } \\
\text { for Trans- } \\
\text { mittal }\end{array}$ & $\begin{array}{l}\text { Origi- } \\
\text { nator } \\
\text { Dispo- } \\
\text { sition }\end{array}$ & $\begin{array}{l}\text { Receiver } \\
\text { Disposition }\end{array}$ \\
\hline l & SNF-5047 & N/A & 0 & $\begin{array}{l}200 \text { Area Interim Storage Area } \\
\text { Teclinical Safety Requirements }\end{array}$ & $\mathrm{S}, \mathrm{Q}, \mathrm{D}$ & 1,2 & 1 & 1 \\
\hline & & & & & & & & \\
\hline & & & & & & & & \\
\hline & & & & & & & & \\
\hline & & & & & & & & \\
\hline & & & & & & & & \\
\hline
\end{tabular}

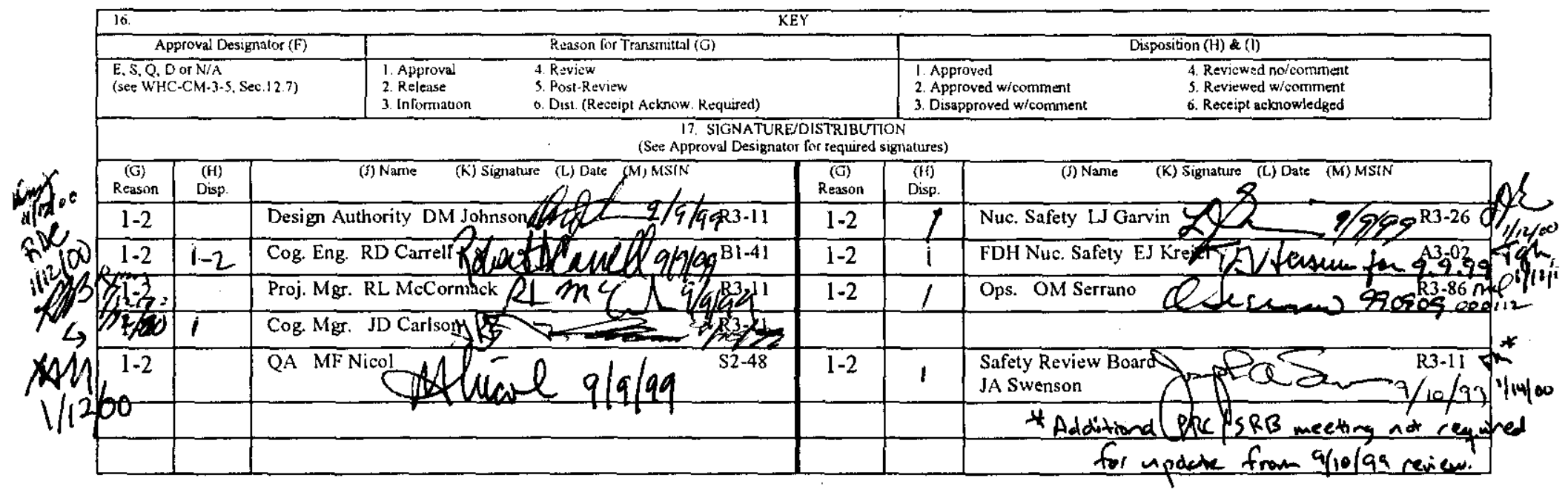

\begin{tabular}{|c|c|c|c|}
\hline 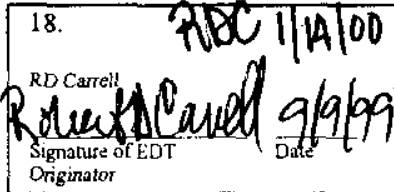 & 19. & 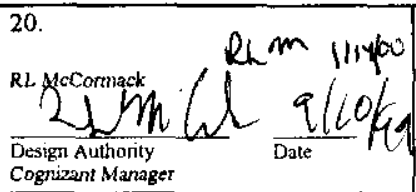 & $\begin{array}{l}\text { 21. DOE APPROVAL (if required) } \\
\text { Ctrl. No. } \\
\text { A Approved by Ke.th A Klein per } \\
\text { [1 Approved w/comments letter } \\
\text { [1 Disapproved w/comments } 2 / 25 / 100 \\
\text { on } 2 / 255\end{array}$ \\
\hline
\end{tabular}

BD-7400-172-2 (05/96) GEF097 


\section{Area Interim Storage Area Technical Safety Requirements}

EDT: 626892

Prepared for the U.S. Department of Energy

Assistant Secretary for Environmental Management

Project Hanford Management Contractor for the

U.S. Department of Energy under Contract DE-AC06-96RL13200

Fluor Hanford

P.O. Box 1000

Richland, Washington 


\section{Area Interim Storage Area Technical Safety Requirements}

R. L. McCormack

Fluor Hanford

Total Pages 53

EDT: 626892

Date Published

January 2000

Prepared for the U.S. Department of Energy

Assistant Secretary for Environmental Management

\section{Fluor Hanford}

P.O. Box 1000

Richland, Washington

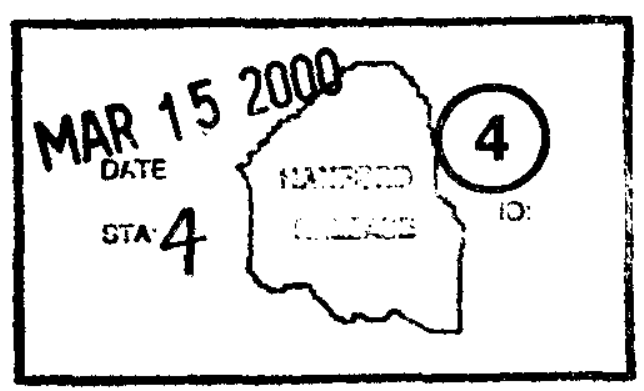




\section{INFORMATION CLEARANCE FORM}

A. Information Category

$\square$ Abstract

$\square$ Summary

$\square$ Visual Aid

$\square$ Full Paper

$\square$ Other

\section{B. Document Number $\$ N E-5047$}

C. Title

200 Area Interim Storage Area Technical Safety Requirements

$\square$ internet

$\square$ Software

$\bigotimes$ Report
E. Required Information

1. Is document potentially Classified? ONo OYes (MANDATORY) Manager's Signature Required

If Yes ADC Signature Required

2. Internal Review Required? If Yes, Document Signatures Below

Ono Oyes classified Counse

Program

3. References in the Information are Applied Technology Export Controlled Information
Ono OYes
4 .

Does Information Contain the Following: (MANDATORY)

a. New or Novel (Patentable) Subject Matter? ONo OYes

If "Yes", Disclosure No.:

b. Information Received in Confidence, Such as Proprietary and/or Inventions?

ONo OYes If "Yes", Affix Appropriate Legends/Notices.
c. Copyrights? ONo OYes
If "Yes", Attach Permission.
d. Trademarks? ONo OYes
If "Yes", Identify in Document.

5. Is Information requiring submission to OSTI? $\bigcirc$ No $\bigcirc$ Yes

If Yes $U C-$

6. Release Level? $\bigcirc$ Public $\bigcirc$ Limited

7. Charge Code 105691

F. Complete for a Journal Article

1. Title of Journal

G. Complete for a Presentation

1. Title for Conference or Meeting

2. Group Sponsoring

3. Date of Conference

4. City/State

5. Will Information be Published in Proceedings? $\bigcirc$ No $\bigcirc$ Yes

6. Will Material be Handed Out? $\bigcirc$ No $\bigcirc$ Yes H. Author/Requestor
Robert D. Carrell (Print and Sign)

\begin{tabular}{|c|c|c|c|c|}
\hline 1. Reviewers & Yes & Print & Signature & Public Y/N (If N, complete J) \\
\hline General Counsel & & & & $\mathrm{Y} / \mathrm{N}$ \\
\hline Office of External Affairs & & & & $\mathrm{Y} / \mathrm{N}$ \\
\hline DOE-RL & $\square$ & & & $\mathrm{Y} / \mathrm{N}$ \\
\hline Other & & & & $\mathrm{Y} / \mathrm{N}$ \\
\hline Other & $\square$ & & & $\mathrm{Y} / \mathrm{N}$ \\
\hline J. If Information Includes S & nniti & Information and is no & blic indicate & \\
\hline$\square$ Applied Technology & & otected CRADA & & \\
\hline$\square$ Personal/Private & & port Controlled & & \\
\hline$\square$ Proprietary & & ocurement-Sensitive & & 17 \\
\hline$\square$ Business-Sensitive & $\square$ & tentable & & \\
\hline$\square$ Predecisional & & her (Specify) & & \\
\hline
\end{tabular}

K. If Additional Comments, Please Attach Separate Sheet 


\section{RELEASE AUTHORIZATION}

\begin{tabular}{ll}
\hline Document Number: & SNF-5047, Rev 0 \\
\hline Document Title: & $\begin{array}{l}\text { 200 Area Interim Storage Area Technical Safety } \\
\text { Requirements }\end{array}$ \\
\hline
\end{tabular}

This document, reviewed in accordance with DOE Order 241.1, "Scientific and Technical Information Management," and 241.1-1, "Guide to the Management of Scientific and Technical Information," does not contain classified or sensitive unclassified information and is:

\section{APPROVED FOR PUBLIC RELEASE}

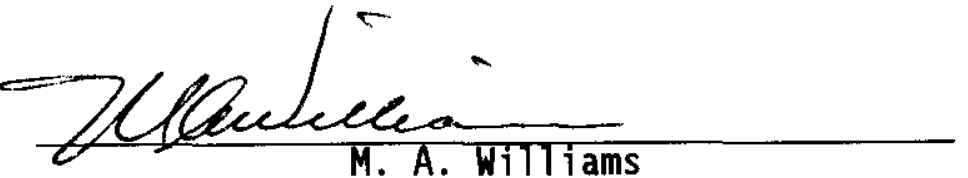

Lockheed Martin Services, Inc. Document Control/Information Clearance

Roviowed for Applied Technology, Business Sensitive, Claseified, Copyrighted, Export Controllod, Patent, Personal/Private, Propnetary, Protected CRADA, Trademark, Unclassified Controlled Nuclear Information.

LEGAL DISCLAIMER. This report was prepared as an account of work eponsored by an agency of the United States Government. Neither the United States Government nor any agency thereof, not any of their employees, nor any of their contractors, subcontractors or their employees, makes any warranty, exprese or implied, or assumes any legal liability or responsibility for the accuracy.

completeness, or any third party's use or the resulte of such use of any information, apparatus, product, or process disclosed, or represente that its use would not infringe privately owned rights. Reference herein to any epecific commercial product, process, or service by trade name, trademark, manufacturer, or otherwise, does not necesearily contitute or imply ite endoreement, recommendation, or favoring by the United States Govemment or any agency thereof or its contractore or subcontractore. The views and opinions of authors expressed herein do not necessarily state or reflect those of the United States Government or any agency thereof. This report has been reproduced from the best available copy. Printed in the United States of America. 


\section{LEGAL DISCLAIMER}

This report was prepared as an account of work sponsored by an agency of the United States Government. Neither the

United States Government nor any agency thereof, nor any of their employees, nor any of their contractors, subcontractors or their employees, makes any warranty, express or implied, or assumes any legal liability or responsibility for the accuracy, completeness, or any third party's use or the results of such use of any information, apparatus, product, or process disclosed, or represents that its use would not infringe privately owned rights. Reference herein to any specific commercial product, process, or service by trade name, trademark, manufacturer, or otherwise, does not necessarily constitute or imply its endorsement, recommendation, or favoring by the United States Government or any agency thereof or its contractors or subcontractors. The views and opinions of authors expressed herein do not necessarily state or reflect those of the United States Government or any agency thereof.

This report has been reproduced from the best available copy. Available in paper copy and microfiche.

Available electronically at http://www.doe.gov/bridge. Available for a processing fee to the U.S. Department of Energy and its contractors, in paper, from:

U.S. Department of Energy

Office of Scientific and Technical Information

P.O. Box 62

Oak Ridge, TN 37831-0062

phone: $865-576-8401$

fax: 865-576-5728

email: reports@adonis.osti.gov(423)576-8401

Printed in the United States of America 
SNF-5407, Rev. 0

Key Words: Spent Nuclear Fuel Project, Interim Storage Area, TSR, Technical Safety Requirment

Abstract: The 200 Area Interim Storage Area Technical Safety Requirements define administrative controls and design features required to ensure safe operation during receipt and storage of canisters containing spent nuclear fuel. This document is based on the 200 Area Interim Storage Area, Annex D, Final Safety Analysis Report which contains information specific to the 200 Area Interim Storage Area. 


\section{AREA INTERIM STORAGE AREA TECHNICAL SAFETY REQUIREMENTS}




\section{PREFACE}

The Technical Safety Requirements (TSRs) for the 200 Area Interim Storage Area (ISA) define Administrative Controls ( $\mathrm{ACs}$ ) required to ensure safe operation during receipt and storage of canisters containing spent nuclear fuel. Controls required for public safety, significant defense-in-depth, significant worker safety, and for maintaining radiological and toxicological consequences below risk evaluation guidelines are included.

The TSRs are based on the preventive and mitigative features determined to be essential in HNF-3553, Spent Nuclear Fuel Project Final Safety Analysis Report, Annex D, "200 Area Interim Storage Area Safety Analysis Report," which is based on DOE 5480.23, Nuclear Safety Analysis Reports. The ISA TSRs constitute an agreement or contract between the U.S. Department of Energy (DOE) and Fluor Hanford regarding the safe operation of the ISA. Once approved, the TSRs cannot be changed without the approval of the Cognizant Secretarial Officer (CSO), or designee.

The format and content for the ISA TSRs are based on DOE 5480.22, Technical Safety Requirements; HNF-PRO-700, Safety Analysis and Technical Safety Requirements; NUREG 1431, Standard Technical Specifications, Westinghouse Plants, and HNF-SD-MP-TSR-001, TSR Writers' Guide. The TSRs will be maintained as a separate, controlled document SNF-5047, 200 Area Interim Storage Area Technical Safety Requirements.

The TSRs apply to the handling and interim storage of non-defense reactor spent nuclear fuel (SNF) housed in dry cask storage systems. The three different dry cask storage systems used at the ISA are as follow:

- Interim Storage Cask (ISC) used for the Fast Flux Test Facility (FFTF) SNF

- Neutron Radiography Facility (NRF) Training, Research, and Isotope Production General Atomics (TRIGA ${ }^{\circledR 1}$ ) casks and U.S. Department of Transportation (DOT)-6M containers within a Chem-Nuclear Services, Incorporated, Rad-Vault ${ }^{\mathrm{TM}} 2$ storage vault used for NRF TRIGA SNF

- $\quad$ Nuclear Assurance Corporation (NAC)-1 casks within International Standards Organization (ISO) containers used for commercial light water reactor (LWR) SNF from the 300 Area.

The ISA TSRs do not specifically cover environmental regulatory requirements, i.e., those contained in the 40 series of the Code of Federal Regulations, "Protection of Environment." Environmental protection is assured as part of the ISA environmental compliance program.

1 TRIGA is a registered trademark of Gulf General Atomics Company, Inc.

2 Rad-Vault is a trademark of Chem-Nuclear Systems, Inc. 
Protection of occupational workers from radiological and toxicological hazards is achieved by hardware systems and integrated safety management programs that ensure control and discipline of operations for added prevention. The programs are detailed in respective regulatory and contractual systems of basic requirements. The safety management programs applicable to the ISA are discussed in the programmatic chapters of HNF-3553, Spent Nuclear Fuel Project Final Safety Analysis Report, Annex D, "200 Area Interim Storage Area Safety Analysis Report," and therefore, are not included in the TSRs. 


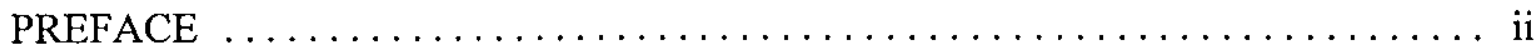
TABLE OF CONTENTS $\ldots \ldots \ldots \ldots \ldots \ldots \ldots \ldots \ldots \ldots \ldots \ldots \ldots \ldots \ldots \ldots$ iv LIST OF TERMS $\ldots \ldots \ldots \ldots \ldots \ldots \ldots \ldots \ldots \ldots \ldots \ldots \ldots \ldots \ldots \ldots, \ldots \ldots \ldots$

Section $1 \quad$ USE AND APPLICATION $\ldots \ldots \ldots \ldots \ldots \ldots \ldots \ldots \ldots \ldots \ldots \ldots \ldots \ldots \ldots \ldots$

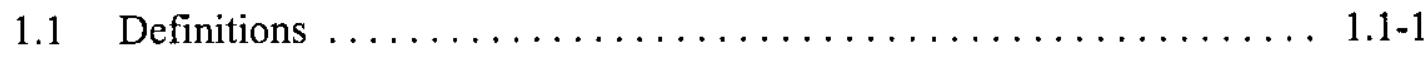

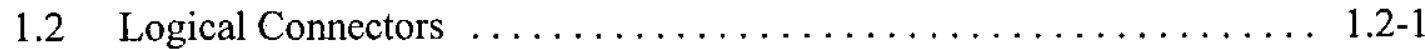

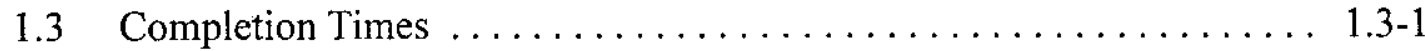

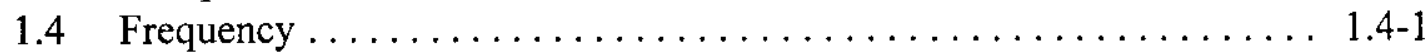

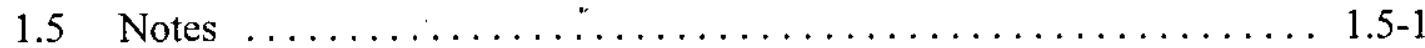

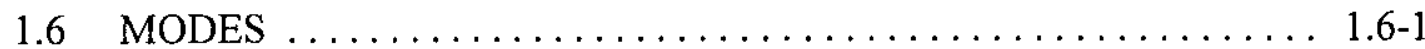

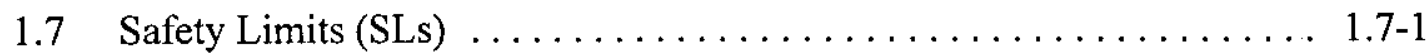

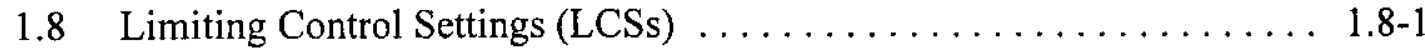

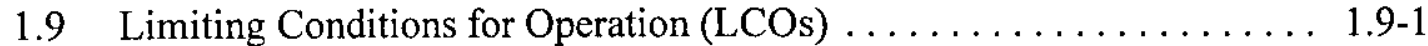

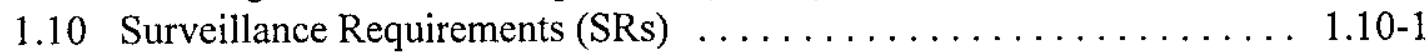

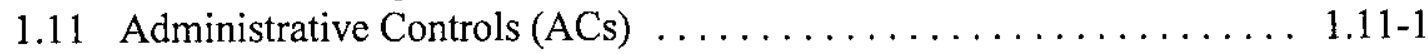

1.12 Cross References ............................... 12-1

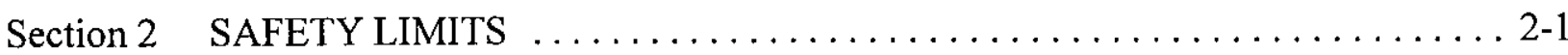

Section 3 OPERATING LIMITS AND SURVEILLANCE REQUIREMENTS $\ldots \ldots \ldots$ 3-1

Section 4 SURVEILLANCE REQUIREMENTS $\ldots \ldots \ldots \ldots \ldots \ldots \ldots \ldots \ldots \ldots .4$

Section $5 \quad$ ADMINISTRATIVE CONTROLS $\ldots \ldots \ldots \ldots \ldots \ldots \ldots \ldots \ldots \ldots \ldots \ldots \ldots \ldots$

5.0 ADMINISTRATIVE CONTROLS (ACs) $\ldots \ldots \ldots \ldots \ldots \ldots \ldots \ldots \ldots .1-1$

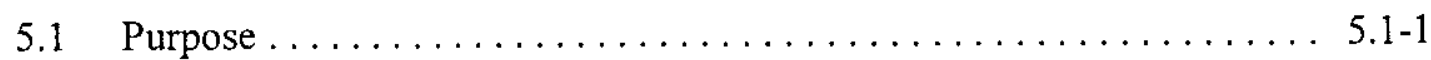

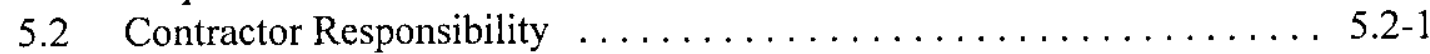

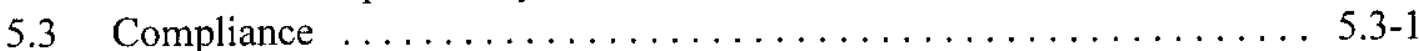

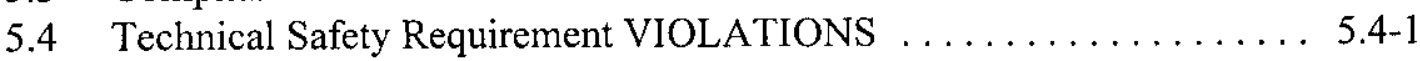

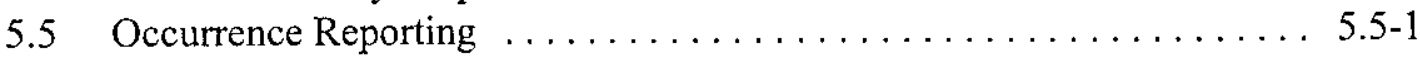

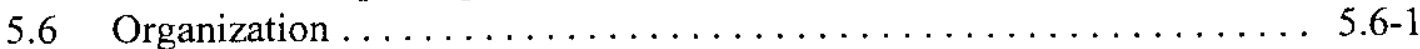

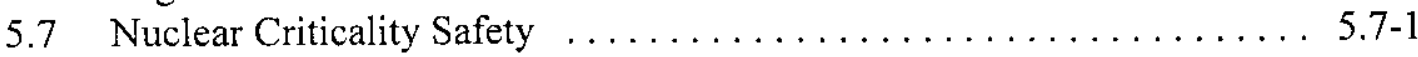

5.8 Source Inventory Receipt Acceptance $\ldots \ldots \ldots \ldots \ldots \ldots \ldots \ldots$. $5.8-1$ 
Table of Contents (continued)

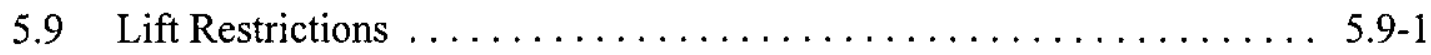

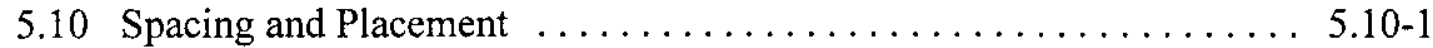

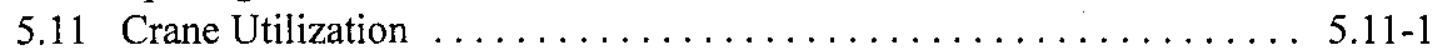

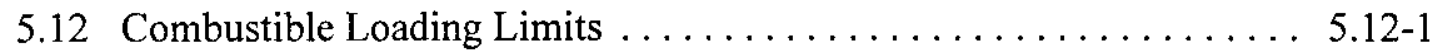

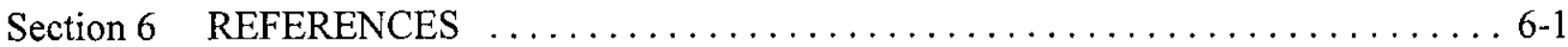

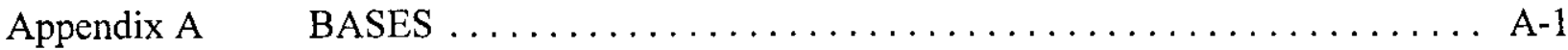

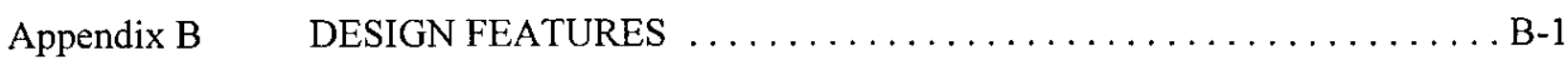




\section{List of Terms}

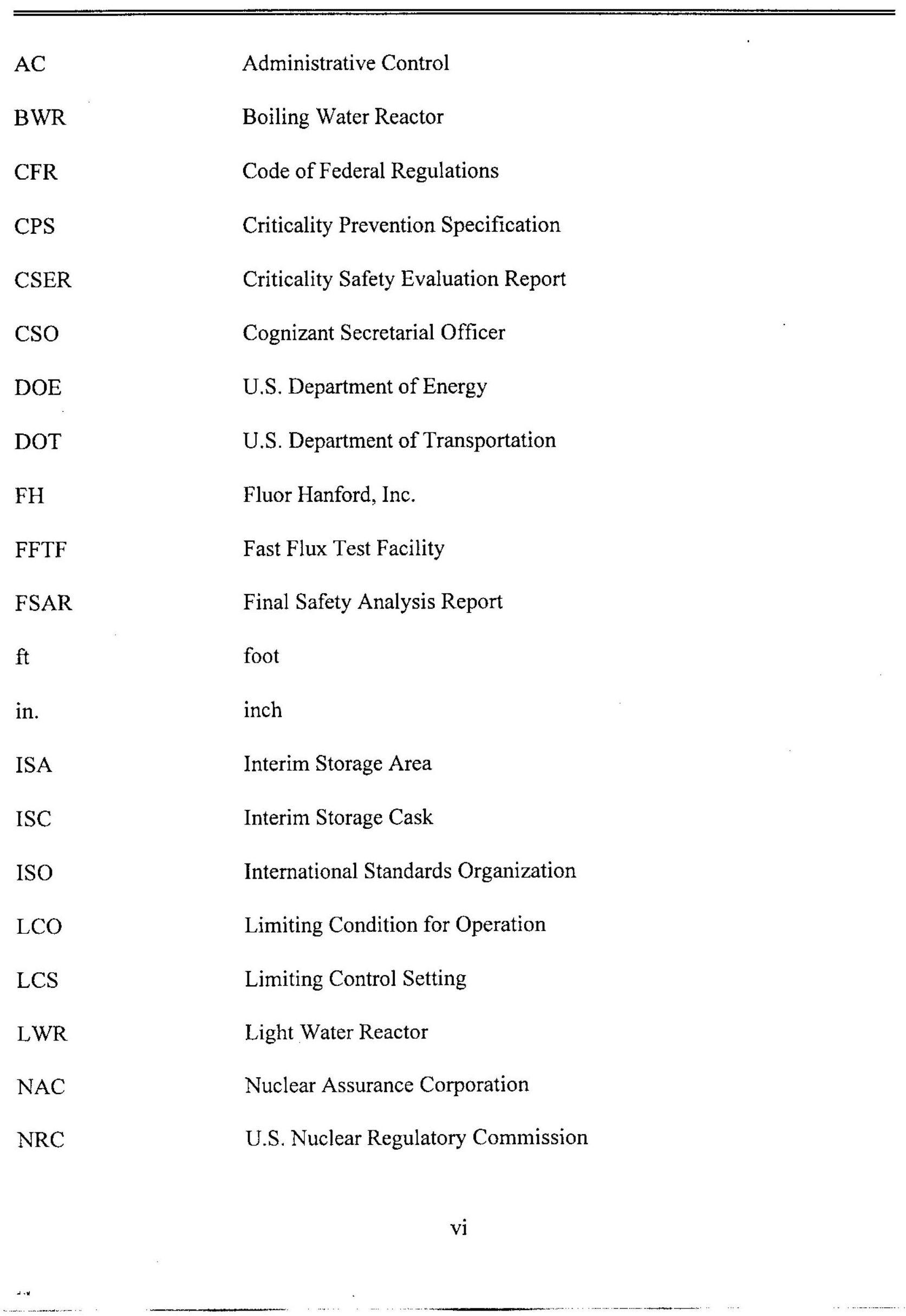




\begin{tabular}{ll} 
NRF & Neutron Radiography Facility \\
NUREG & NRC Technical Report Designation (Nuclear Regulatory Commission) \\
PWR & Pressurized Water Reactor \\
SAR & Safety Analysis Report \\
SL & Safety Limit \\
SNF & Spent Nuclear Fuel \\
SR & Surveillance Requirement \\
SSCs & Structures, Systems, and Components \\
TRIGA & Training, Research, and Isotope Production General Atomics \\
TSR & Technical Safety Requirement \\
\hline \hline
\end{tabular}


SECTION 1

USE AND APPLICATION 
Section 1 USE AND APPLICATION

\subsection{Definitions}

-NOTE-

The defined terms of this section are unique definitions. They appear in CAPITALIZED type and are applicable throughout these Technical Safety Requirements (TSRs) and BASES. Some terms in this section refer the user to another section for the definition. This approach will prevent a shortened definition from being supplied and used out of context. Source documents from which the definitions are taken are referenced at the end of each definition. Definitions that have been annotated technically, are noted as such.

$\underline{\text { Term }}$

ACTIONS

DESIGN FEATURES

MODE

\section{Definition}

ACTIONS shall be that part of a Limiting Condition for Operation (LCO) that prescribes Required Actions to be taken under designated Conditions within specified Completion Times.

\section{(NUREG 1431)}

DESIGN FEATURES are those design characteristics, primarily passive in nature, that are of a special importance to maintaining adequate control, shielding, or containment of radiological or toxicological material for which indiscriminate changes are to be prevented. See Appendix B, "DESIGN FEATURES," for DESIGN FEATURES criteria.

MODES are used (1) to determine SL, LCS, LCO, and AC program applicabilities, (2) to distinguish facility operational conditions, (3) to determine minimum staffing requirements, and (4) to provide an instant facility status report. See also Section 1.6, "MODES."

(DOE 5480.22) - annotated. 
1.1 Definitions (continued)

OPERABLE/OPERABILITY A system, subsystem, train, component, or device shall be OPERABLE or have OPERABILITY when it is capable of performing its specified safety function(s), and (a) set points are within limits, (b) operating parameters necessary for OPERABILITY are within limits, and (c) when all necessary attendant instrumentation, controls, electrical power, cooling or seal water, lubrication, or other auxiliary equipment that are required for the system, subsystem, train, component, or device to perform its safety function(s) are also capable of performing their related safety support function(s).

(DOE 5480.22) - annotated.

VERIFY/VERIFICATION A qualitative assessment to confirm or substantiate that specific plant conditions exist. This may include collecting sample data or quantitative data; taking instrument readings; recording data and information on logs, data sheets, or electronic media; and evaluating data and information according to procedures.

VIOLATION See Section 5.4, "Technical Safety Requirement VIOLATIONS." (DOE 5480.22) - annotated. 


\section{Section 1 USE AND APPLICATION}

\subsection{Logical Connectors}

Logical connectors are used in TSRs to discriminate between, and yet connect, discrete Conditions, Required Actions, Completion Times, Surveillances and Frequencies. The only logical connectors that appear in TSRs are $\underline{\text { AND }}$ and $\underline{\mathrm{OR}}$. The physical arrangement of these connectors constitutes logical conventions with specific meanings.

This section does not apply to the ISA because there are no logical connectors specified in these TSRs. 


\section{Section 1 USE AND APPLICATION}

\subsection{Completion Times}

The Completion Time is the amount of time allowed for completing a Required Action. It is referenced to the time of discovery of a situation (e.g., inoperable equipment or variable not within limits) that requires entering an ACTIONS Condition unless otherwise specified, provided the unit is in a MODE or specified condition stated in the Applicability of the LCO.

This section does not apply to the ISA because there are no LCOs specified in these TSRs. 


\section{Section 1 USE AND APPLICATION}

\subsection{Frequency}

Each Surveillance Requirement (SR) has a specified Frequency in which the Surveillance must be met in order to meet the associated Limiting Condition for Operation (LCO).

This section does not apply to the ISA because there are no SRs or LCOs specified in these TSRs. 
Section 1 USE AND APPLICATION

\subsection{Notes}

Notes provide additional clarification in the Limiting Conditions for Operation (LCOs), Applicability, ACTIONS and Surveillance Requirements (SRs). Notes in the LCOs and Applicability are placed after the text they amplify. Notes in the ACTIONS and SRs are placed before the text they amplify. All Notes are preceded by the centered heading "NOTE" in uppercase type. 
Section 1 USE AND APPLICATION

\subsection{MODES}

The only MODE for the ISA is defined as follows:

OPERATION
Activities involving handling and storage of fissile material in storage containers. This MODE includes receipt, handling, and placement of storage casks along with routine surveillance and maintenance activities. 


\section{Section 1 USE AND APPLICATION}

\subsection{Safety Limits (SLs)}

SLs are limits on process variables (e.g., temperature, pressure) associated with those physical barriers (e.g., tanks, piping), generally passive, that are necessary for the intended facility function. Exceeding SLs could directly cause the failure of one or more of the barriers that prevent the uncontrolled release of radiological and toxicological material. The limits are stated in measurable units such as degrees Celsius and are placed on primary barriers closest to the material source. SLs are reserved for a small set of safety requirements to which the facility is committed to protect the integrity of the primary barriers.

There are no SLs associated with the ISA TSRs. 


\section{Section 1 USE AND APPLICATION}

\subsection{Limiting Control Settings (LCSs)}

LCSs are set points on safety systems that control process variables to prevent exceeding SLs. The specific set points are chosen such that if exceeded, sufficient time is available to automatically or manually correct the condition before exceeding SLs.

The LCSs are combined with their respective LCOs with all set points and requirements contained within the LCOs. By combining the LCSs with the LCOs, the LCS set point (within limits) becomes part of the OPERABILITY of the system. Furthermore, safety is enhanced by placing the Applicability, ACTIONS, and SRs for a system in a single location and reduces the complexity of the TSR document.

There are no LCSs associated with the ISA TSRs. 


\section{Section 1 USE AND APPLICATION}

\subsection{Limiting Conditions for Operation (LCOs)}

LCOs are the lowest functional capability or performance level of safety structures, systems, and components (SSCs) (and their support systems) required for normal, safe operation of the facility. LCOs are based on keeping the safety SSCs OPERABLE, or on maintaining conditions within specified limits. LCOs are prepared for those safety SSCs that are identified in the accident analyses as preventing or mitigating accidents or transient events that involve the assumed failure of, or present a challenge to, the integrity of a physical barrier that prevents the uncontrolled release of radiological and toxicological material. LCOs are established only for those mitigative safety SSCs that are part of the primary success path of an accident sequence analysis; i.e., the assumed sequence of events that leads to the conclusion of an accident for which the risk is judged to be acceptable.

There are no LCOs associated with the ISA TSRs. 


\section{Section 1 USE AND APPLICATION}

\subsection{Surveillance Requirements (SRs)}

SRs are requirements relating to testing, calibration, or inspection of SSCs or conditions. The purpose of SRs is to confirm the availability, OPERABILITY, and quality of safety SSCs, or VERIFY that specific plant conditions exist that are required to maintain the facility's operations within the SLs, LCSs, and LCOs. SRs ensure that safety SSCs will function when required or that parameters are within limits (e.g., temperature) to preserve the validity of the safety analysis and the resulting safety envelope. If a safety SSC is out of service or is inoperable, it cannot perform its required safety function.

There are no SRs associated with the ISA TSRs because there are no SLs, LCSs, or LCOs. 


\section{Section 1 USE AND APPLICATION}

\subsection{Administrative Controls (ACs)}

ACs are the provisions relating to organization and management, procedures, record keeping, reviews, audits, and specific program requirements for risk reduction necessary to ensure safe operation of the facility. The TSRs (i.e., SLs, LCSs, LCOs and ACs) establish administrative requirements that ensure TSR requirements are met in the operation of the facility and the procedures that are followed should a TSR not be met. ACs are normally written at the program level and contain program key elements, as applicable. ACs are established (1) if a safety function is best satisfied by a program instead of a hardware system, (2) if control of a condition is not measured in real-time or near to real-time, (3) if control of a condition is not under the immediate control of the operator, (4) if a condition does not require immediate action and sufficient recovery time exists to permit mitigating action, or (5) if a condition requires an evaluation based on prevalent conditions. ACs do not require ACTIONS statements or SRs. SRs necessary to demonstrate compliance with an $\mathrm{AC}$ and the actions taken should an $\mathrm{AC}$ requirement not be met are performed according to procedures.

ACs are established for those programs required to prevent or mitigate accidents with unacceptable radiological or toxicological consequences to the offsite public or onsite worker, to provide significant defense in depth, or provide significant worker safety. Quantitative risk evaluation guidelines are provided for the Spent Nuclear Fuel Project facilities in HNF-3553, Spent Nuclear Fuel Project Final Safety Analysis Report, Chapter 3.0, "Hazard and Accident Analyses." 
Section 1 USE AND APPLICATION

\subsection{Cross References}

Cross References direct the TSR user to other SLs, LCSs, LCOs, and ACs that are related to the SLs, LCSs and LCOs where the Cross Reference section is located. The purpose of the Cross Reference section is to make the TSR user aware that there may be other TSR controls or requirements that apply concurrently when a situation or condition is discovered.

There are no Cross References associated with the ISA TSRs because there are no SLs, LCSs, or LCOs. 


\section{SECTION 2}

\section{SAFETY LIMITS}




\subsection{SAFETY LIMITS}

There are no Safety Limits associated with operating the 200 Area Interim Storage Area. 


\section{SECTION 3}

\section{OPERATING LIMITS}

AND

\section{SURVEILLANCE REQUIREMENTS}




\subsection{LIMITING CONDITIONS FOR OPERATION (LCOs)}

There are no Limiting Control Settings or Limiting Conditions for Operation associated with operating the 200 Area Interim Storage Area. 


\section{SECTION 4}

\section{SURVEILLANCE REQUIREMENTS}




\subsection{SURVEILLANCE REQUIREMENTS (SRs)}

There are no Surveillance Requirements associated with operating the 200 Area Interim Storage Area. 
SECTION 5

ADMINISTRATIVE CONTROLS 


\subsection{ADMINISTRATIVE CONTROLS (ACs)}

\subsection{Purpose}

5.1.1 The purpose of the Administrative Controls (ACs) is to state the provisions relating to organization and management, procedures, record keeping, reviews, audits, and specific program requirements for risk reduction necessary to ensure safe operation of the ISA.

5.1 .2

Applicability

Unless otherwise noted, these ACs apply during all MODES (OPERATION) to the ISA. 


\subsection{ADMINISTRATIVE CONTROLS (ACs)}

\subsection{Contractor Responsibility}

5.2.1 Fluor Hanford, is responsible to the U.S. Department of Energy (DOE) for the safe operation of the DOE-owned ISA in accordance with the Technical Safety Requirements (TSRs) as approved by the Cognizant Secretarial Officer (CSO), or designee, including any modification by the CSO. The contractor shall be responsible for maintaining the current DOE-approved TSRs as a controlled document.

CSB Facility Operations Manager

The CSB Facility Operations Manager, or designee, shall be responsible for overall ISA operation and shall delegate in writing the succession to this responsibility, as appropriate.

CSB Shift Operations Manager

The CSB Shift Operations Manager, or designee, shall be responsible for managing the shift operations and maintenance of the 200 Area ISA.

\section{CSB Facility Manager}

The CSB Facility Manager, or designee, shall be responsible for the local command function. During any absence of the CSB Facility Manager from the facility, a designated, qualified individual shall assume the command function. 


\subsection{ADMINISTRATIVE CONTROLS (ACs)}

\subsection{Compliance}

5.3.1 The CSB Facility Operations Manager is responsible for ensuring that the requirements of the ISA TSRs are met. Compliance shall be demonstrated by:

a. Establishing, implementing, and maintaining the required ACs.

b. Maintaining required DESIGN FEATURES. 


\subsection{ADMINISTRATIVE CONTROLS (ACs)}

5.4 Technical Safety Requirement VIOLATIONS

5.4 .1

5.4 .2

\section{4 .5}

VIOLATION Criteria

VIOLATIONS of the TSRs occur for failure to comply with an AC requirement.

NOTE

$\mathrm{AC}$ requirements are found in each $\mathrm{AC}$ program requirement section. Minimum requirements for each $\mathrm{AC}$ program are found in the program key elements section. Failure to comply with an $\mathrm{AC}$ program or the intent of an AC program is considered a VIOLATION. A noncompliance within a specific procedure that implements an AC program is not necessarily a VIOLATION.

\section{Response to a Safety Limit VIOLATION}

This section is not applicable because there are no SLs associated with ISA TSRs.

Response to a Limiting Condition for Operation and Limiting Control Setting VIOLATION

This section is not applicable because there are no LCOs or LCSs associated with ISA TSRs.

Response to a Surveillance Requirement VIOLATION

This section is not applicable because there are no SRs associated with ISA TSRs.

Response to an AC VIOLATION

If a VIOLATION of an AC occurs, proceed as follows:

a. Notify the DOE of the VIOLATION and prepare an occurrence report in accordance with Section 5.5, "Occurrence Reporting."

b. Prepare a recovery plan describing the steps leading to compliance with the AC.

c. Perform and document a technical evaluation, if appropriate, of the AC VIOLATION to determine if any damage may have occurred. 


\subsection{ADMINISTRATIVE CONTROLS (ACs)}

\subsection{Occurrence Reporting}

\subsection{1 $\quad$ Requirement for Occurrence Reporting}

A program shall be established, implemented, and maintained for occurrence reporting of events and conditions, which may involve health and safety. It is the policy of Fluor Hanford to encourage a positive attitude toward reporting occurrences. Consistent reporting of occurrences assures that both DOE and contractor line management are kept fully and currently informed of all events which could have the following results: (1) affect the health and safety of the public or (2) endanger the health and safety of workers.

\subsection{2 $\quad$ Program Key Elements}

The program key elements include the following:

a. Timely identification, categorization, notification, and reporting to DOE and contractor management of all reportable.

b. Timely evaluation of and implementation of appropriate corrective actions.

c. Review of reportable occurrences to assess significance, root causes, generic implications, and the basis for any corrective actions taken to prevent recurrence.

TSR VIOLATIONS shall be reported in accordance with DOE occurrence reporting requirements. 


\subsection{ADMINISTRATIVE CONTROLS (ACs)}

\subsection{Organization}

5.6 .1

5.6.1.1

5.6 .1 .2
Lines of authority, responsibility, and communication shall be established and defined for the highest management levels through intermediate levels to and including all safety and operating organization positions. These relationships shall be documented and updated, as appropriate, in the form of organization charts, functional descriptions of departmental responsibilities and relationships, and job descriptions for key personnel positions, or in equivalent forms of documentation.

The individuals who train the operating staff and those who carry out safety and quality assurance functions shall have sufficient organizational freedom to ensure their independence from operating pressures.

\section{CSB Facility Operations Manager}

The CSB Facility Operations Manager shall be responsible for safe operation within the facility. Safe operation shall include, as necessary, interface requirements with other onsite organizations and facilities.

\section{Minimum Operations Shift Complement}

The number of Shift Managers and operators available shall be adequate to operate and support the ISA safely. Abnormal plant conditions shall be considered in determining operator assignments. Management shall provide additional personnel, as necessary, to support other activities.

The 200 Area ISA is normally an unmanned facility. The facility is staffed when placing or retrieving storage casks and containers and during maintenance and surveillance activities. Assignment of radiological and maintenance personnel on a periodic basis is considered adequate to perform the inspections, surveillance, repairs, and monitoring necessary to protect the health and safety of the public and the collocated worker. 


\subsection{ADMINISTRATIVE CONTROLS (ACs)}

5.7 Nuclear Criticality Safety

5.7.1 $\quad$ Requirement for Nuclear Criticality Safety

A program shall be established, implemented, and maintained to prevent an accidental criticality at the 200 Area Interim Storage Area.

Program Key Elements

a. Criticality limits and controls shall be documented in Criticality Safety Evaluation Reports (CSERs) and implemented in Criticality Prevention Specifications (CPSs) and procedures.

b. Procedures shall be established for recovery from a CPS nonconformance.

c. Criticality safety training shall be provided for operations and technical personnel.

5.7.3 Applicability

This program applies to OPERATION MODE. 


\subsection{ADMINISTRATIVE CONTROLS (ACs)}

5.8 Source Inventory Receipt Acceptance

5.8 .1

\section{Requirement for Receipt Acceptance}

A program shall be established, implemented, and maintained to ensure that the 200 Area Interim Storage Area (ISA) only accepts hazardous and radiological material that has been authorized in the facility Safety Analysis Report (SAR).

\section{Program Key Elements}

a. Acceptance criteria shall be established such that fuel type, quantity, and configuration are limited to those analyzed in the facility SAR. The criteria shall include the following:

- There shall be no more than seven fuel assemblies in a CCC.

- Each CCC shall contain six DFAs in the outer positions, seven DFAs including the center position, or six Ident-69 containers in the outer positions. The loaded CCC can contain a mixture of fuel assemblies and pin containers such that the total is either six or seven, and the number of pin containers is five or less. No partially filled CCCs are permitted.

- There shall be no more than a total of 1,519 pins in a CCC container to protect the fuel rod rupture pressure calculation assumptions.

- Only intact fuel shall be placed into a CCC or an LWR canister.

- The number of individual fuel rods in the NAC-1 cask shall not exceed a maximum of 179 PWR rods or $96.5 \mathrm{BWR}$ rods consolidated with 17 PWR rods. 
5.8 Source Inventory Receipt Acceptance (continued)

5.8.2 (continued) b. Procedures shall be established to ensure shipments meet acceptance criteria.

c. Records shall be kept, maintained, and available for review that material stored at the ISA meets the acceptance criteria.

Applicability

This program applies to OPERATION MODE. 


\subsection{ADMINISTRATIVE CONTROLS (ACs)}

\subsection{1 $\quad$ Requirement for Lift Restrictions}

A program shall be established, implemented, and maintained to ensure that maximum lift heights are not exceeded and prohibited objects are not crossed over.

Program Key Elements

a. The following lift restrictions are applied to the ISC:

- The ISC shall not be lifted more than 8 feet above the ground or storage pad.

- The ISC shall not be lifted over objects containing radioactive materials or an object that is higher than $4 \mathrm{ft}$. from ground or pad.

- Crane loads other than ISC rigging shall not be operated over a loaded ISC.

b. The following lift restrictions are applied to the Rad-Vault, NRF TRIGA casks, and DOT-6M containers:

- Rad-Vault can only be lifted empty with cover removed.

- Crane loads other than NRF TRIGA casks, DOT-6M containers, rigging and the Rad-Vault cover shall not be handled over a loaded Rad-Vault.

- The Rad-Vault cover shall not be handled at a height greater than 12 in. above the top of the Rad-Vault. 
5.9 .2

(continued)
- The NRF TRIGA cask maximum handling lift height shall not exceed $109 \mathrm{in}$. (approximately $9.1 \mathrm{ft}$.) above the ground or storage pad. This lift height is equivalent to $21 \mathrm{in}$. above the top of the Rad-Vault (with the lid removed).

- The DOT-6M container maximum handling lift height shall not exceed 109 in. (approximately $9.1 \mathrm{ft}$.) above the ground or storage pad. This lift height is equivalent to $21 \mathrm{in}$. above the top of the Rad-Vault (with the lid removed).

c. The following lift restrictions are applied to the NAC-1 Cask:

- The NAC-1 Cask maximum lift height shall not exceed $30 \mathrm{ft}$. above the ground or pad.

- The NAC-1 Cask shall not be lifted over other objects except the transport trailer.

- The crane hook and block lift height shall not exceed $56 \mathrm{ft}$. above the ISO/NAC-1 Cask.

- The ISO spreader bar lift height shall not exceed $6 \mathrm{ft}$. above the ISO.

d. Establish a method for indicating maximum lift height (e.g., measuring stick).

e. All lifts are to be considered critical lifts as discussed in the Hanford Site Hoisting and Rigging Manual (DOE/RL-92-36)

This program applies to OPERATIONS MODE. 


\subsection{ADMINISTRATIVE CONTROLS (ACs)}

5.10 Spacing and Placement

5.10.1 Requirement for Spacing and Placement

A program shall be established, implemented, and maintained to ensure that containers are properly placed and spaced.

Program Key Elements

a. Place ISCs and NAC-1 containers only on the concrete storage pads

b. Place ISCs in storage arrays of two rows with edge to edge spacing of at least $44 \mathrm{in}$. between ISCs. One of the three distances may be less than 44 in. (but greater than 24 in) as long as the 44 in. dimension is maintained in the other two directions.

c. Establish a method for indicating proper ISC placement (e.g., painting an area on the storage pad).

d. Verify the ISC is properly positioned on the storage pad and the minimum spacing requirement is met after unloading an ISC from the transport vehicle.

e. Verify the Rad-Vault is properly positioned on the gravel pad before loading the NRF TRIGA casks and DOT-6M containers.

This program applies to OPERATIONS MODE. 


\subsection{ADMINISTRATIVE CONTROLS (ACs)}

\subsection{Crane Utilization}

\subsubsection{Requirement for Crane Utilization}

5.11 .2

A program shall be established, implemented, and maintained to ensure only approved cranes are used in the 200 Area ISA.

Program Key Elements

a. Document and Maintain a list of cranes approved for lifting the ISC, NAC-1 container, NRF TRIGA cask and DOT-6M container.

b. Handle the ISC and NAC-1 container only with a crane from the approved list and bounded by the FSAR.

c. Handle the NRF TRIGA cask and DOT-6M container with any appropriate crane within the Hanford Site hoisting and rigging criteria (DOE/RL-92-36) for a critical lift, but no larger than a 250-ton crane.

\subsubsection{Applicability}

This program applies to OPERATIONS MODE. 


\subsection{ADMINISTRATIVE CONTROLS (ACs)}

5.12 Combustible Loading Limits

\subsubsection{Requirement for Combustible Loading Limits}

A program shall be established, implemented, and maintained to limit the combustible loadings outside of rated fire containers to the quantities and locations allowed in the fire hazard analysis (SNF-4932, Fire Hazard Analysis for the 200 Area Interim Storage Area).

\section{Program Key Elements}

a. The fire hazard analysis shall be reviewed at least annually to ensure that the program complies with the combustible loading limits (quantity and location) within the analysis.

b. The facility's combustible loadings shall be evaluated at least annually and compared against the fire hazard analysis limits. Any necessary adjustments shall be made to comply with the fire hazard analysis loading limitations.

\subsubsection{Applicability}

This program applies to OPERATIONS MODE. 
SECTION 6

REFERENCES 
DOE 5480.21, 1991, Unreviewed Safety Questions, U.S. Department of Energy, Washington, D.C.

DOE 5480.22, 1992, Technical Safety Requirements, Change 1 (1992), and Change 2 (1996), U.S. Department of Energy, Washington, D.C.

DOE 5480.23, 1992, Nuclear Safety Analysis Reports, Change 1 (1994), U.S. Department of Energy, Washington, D.C.

DOE-RL-92-36, 1993, Hanford Site Hoisting and Rigging Manual, U.S. Department of Energy, Richland Operations Office, Richland, Washington

HNF-3553, 1999, Spent Nuclear Fuel Project Final Safety Analysis Report, Rev.0, Fluor Daniel Northwest, Inc., Richland, Washington.

HNF-3553, 1999, Spent Nuclear Fuel Project Final Safety Analysis Report, Rev.0, Annex D, "200 Area Interim Storage Area Final Safety Analysis Report," Fluor Daniel Northwest, Inc., Richland, Washington.

HNF-SD-MP-TSR-001, 1997, TSR Writers' Guide, Rev. 1, Fluor Daniel Northwest, Inc., Richland, Washington.

NUREG 1431, 1992, Standard Technical Specifications, Westinghouse Plants, Rev. 0, U.S. Nuclear Regulatory Commission, Washington D.C.

SNF-4932, 1999, Fire Hazard Analysis for the 200 Area Interim Storage Area, Rev. 0, Fluor Daniel Northwest, Inc., Richland, Washington. 
APPENDIX A

BASES

A-1 
According to DOE Order 5480.22, a BASES appendix is required to summarize the reasons for establishing Safety Limits (SLs), Limiting Conditions for Operation (LCOs), Limiting Control Settings (LCSs), and associated Surveillance Requirements (SRs). This appendix does not apply to the 200 Area ISA because there are no SLs, LCOs, LCS, or SRs. BASES for the Administrative Controls (ACs) of these TSRs are derived from the facility Final Safety Analysis Report (FSAR), HNF-3553, 1999, Spent Nuclear Fuel Project Final Safety Analysis Report, Annex D, "200 Area Interim Storage Area Final Safety Analysis Report," Chapter D5.0, "Derivation of Technical Safety Requirements." 
APPENDIX B

DESIGN FEATURES

B-1 
DESIGN FEATURES are those features not covered elsewhere in the TSRs and that, if altered or modified, would have a significant effect on safety. DESIGN FEATURES are normally permanently built-in features that do not require, or infrequently require, maintenance or surveillance and are normally not subject to change by operations personnel. The categories of DESIGN FEATURES to be addressed in accordance with DOE 5480.22, Technical Safety Requirements, include the following:

a. Vital passive components such as piping, vessels, supports, confinement structures, and containers.

b. Configuration and physical arrangement of the facility where safety is a concern including site characteristics such as the locations of public access roads, collocated facilities, facility area boundaries, site boundaries, and distances to the nearest residences.

c. Building materials, if the safe operation of the facility depends on any component being constructed of a particular material.

Changes to DESIGN FEATURES are considered significant modifications. The change control process in conjunction with the unreviewed safety question (USQ) process required by DOE 5480.21, Unreviewed Safety Questions, ensures that changes to DESIGN FEATURES are appropriately analyzed and controlled so that they do not adversely affect safe operation of the 200 Area ISA.

The DESIGN FEATURES for the ISA that, if altered or modified, would have a significant effect on safe operation are listed in and derived from the facility Final Safety Analysis Report (FSAR), HNF-3553, 1999, Spent Nuclear Fuel Project Final Safety Analysis Report, Annex D, "200 Area Interim Storage Area Final Safety Analysis Report," Chapter D5.0, "Derivation of Technical Safety Requirements." 


\section{DISTRIBUTION SHEET}

\begin{tabular}{|c|c|c|c|c|c|}
\hline \multirow{2}{*}{$\begin{array}{l}\text { To } \\
\text { Distribution }\end{array}$} & \multirow{2}{*}{\multicolumn{3}{|c|}{$\begin{array}{l}\text { From } \\
\text { Site-Wide SNF Project }\end{array}$}} & \multicolumn{2}{|l|}{ Page 1 of 1} \\
\hline & & & & \multicolumn{2}{|l|}{ Date $01 / 12 / 00$} \\
\hline \multicolumn{4}{|l|}{ Project Title/Work Order } & \multicolumn{2}{|c|}{ EDT No. 626892} \\
\hline \multicolumn{4}{|c|}{ SNF-5047, Rev. 0} & \multirow{2}{*}{\multicolumn{2}{|c|}{ ECN No. N/A }} \\
\hline \multicolumn{4}{|c|}{200 Area Interim Storage Area Technical Safety Requirements, Rev. 0} & & \\
\hline Name & MSIN & $\begin{array}{l}\text { Text } \\
\text { With All } \\
\text { Attach. }\end{array}$ & Text Only & $\begin{array}{l}\text { Attach./ } \\
\text { Appendix } \\
\text { Only }\end{array}$ & $\begin{array}{c}\text { EDT/ECN } \\
\text { Only }\end{array}$ \\
\hline
\end{tabular}

R. L Boyleston

R. D. Carrell

R. D. Crowe

L. J. Garvin

D. M. Johnson

E. J. Krejci

R. L. McCormack

M. F. Nicol

O. M. Serrano

J. A. Swenson

D. S. Takasumi

J. E. Turnbaugh

SNF Project Files
R3-26

B1-41

R3-26

R3-26

R3-11

A3-02

R3-11

S2-48

R3-86

R3-11

L1-02

X3-79

R3-11
X

X (3 copies)

X

$\mathrm{X}$

X

$\mathrm{X}$

$X$ (4 copies)

X

X

X

X ( 2 copies)

X

$\mathrm{X}$ 